\title{
Habitat and trophic ecology of Southern Ocean cephalopods from stable isotope analyses
}

\author{
Miguel Guerreiro ${ }^{1, *}$, Richard A. Phillips ${ }^{2}$, Yves Cherel ${ }^{3}$, Filipe R. Ceia ${ }^{1}$, \\ Pedro Alvito ${ }^{1}$, Rui Rosa ${ }^{4}$, José C. Xavier ${ }^{1,2}$ \\ ${ }^{1}$ MARE-Marine and Environmental Sciences Centre, Faculdade de Ciências e Tecnologia, Universidade de Coimbra, \\ 3004-517 Coimbra, Portugal \\ ${ }^{2}$ British Antarctic Survey, Natural Environment Research Council, High Cross, Madingley Road, Cambridge CB3 0ET, \\ United Kingdom \\ ${ }^{3}$ Centre d'Etudes Biologiques de Chizé, UMR 7372 du CNRS-Université de La Rochelle, BP 14, 79360 Villiers-en-Bois, France \\ ${ }^{4}$ Laboratório Marítimo da Guia, Centro de Oceanografia, Faculdade de Ciências da Universidade de Lisboa, \\ Av. Nossa Senhora do Cabo, 939, 2750-374 Cascais, Portugal
}

\begin{abstract}
Although cephalopods play a critical role in marine food webs both as predators and prey, there is a limited knowledge of several basic aspects of their ecology, including their habitat and trophic level, in the Southern Ocean. We examined the ecological role of several Southern Ocean cephalopod species by analyzing $\delta^{13} \mathrm{C}$ and $\delta^{15} \mathrm{~N}$ values in lower cephalopod beaks obtained from diet samples of wandering albatross Diomedea exulans from South Georgia (Atlantic Ocean), and from Crozet and Kerguelen Islands (Indian Ocean). Beak $\delta^{13} \mathrm{C}$ values ranged from -25.7 to $-17.9 \%$, and were used to assign different cephalopod species to the subtropical, subAntarctic or Antarctic Zones. Beak $\delta^{15} \mathrm{~N}$ values were more variable among species, ranging from 2.4 to $13.3 \%$, a difference of $\sim 11 \%$ o that represents approx. 3 trophic levels. Differences among islands in isotope ratios in the same cephalopod species (higher $\delta^{15} \mathrm{~N}$ and lower $\delta^{13} \mathrm{C}$ values in South Georgia) were attributed to regional oceanographic processes. Antarctic cephalopods occupy niches similar to those found in some pelagic fish, seabirds and marine mammals. As cephalopods are key components in Southern Ocean food webs, these results greatly advance our understanding of the structure, energy and carbon flows in this polar ecosystem.
\end{abstract}

KEY WORDS: Southern Ocean · Pelagic ecosystem - Distribution · Foraging ecology · Kondakovia longimana $\cdot$ Diet

\section{INTRODUCTION}

Cephalopods play an important role in the marine food web of the Southern Ocean (here defined as south of the Subtropical Front; see Fig. 1). They are thought to occupy the ecological niche of pelagic fish (Rodhouse \& White 1995), and sustain large populations of top predators in the region (e.g. toothed whales, seals, penguins, albatrosses and petrels), amounting to an estimated total consumption of around 34 million t of cephalopods per annum (Clarke 1983). The cephalopod species that thrive in the Southern Ocean are oegopsid squid and octopods, including species that are entirely Antarctic, and other more cosmopolitan species that either by active migration, or due to their deep-sea distribution, can cross the Antarctic Polar Front (APF) (Collins \& Rodhouse 2006). Southern Ocean cephalopods are those who live south of the Subtropical Front (STF) at around $40^{\circ} \mathrm{S}$ (Fig. 1). Other longitudinal features in the Southern Ocean include the Antarctic Circumpolar Current (ACC), with a clockwise circulation around 
the Antarctic continent in the Atlantic, Indian and Pacific sectors of the Southern Ocean, which deflects northwards at $50-52^{\circ} \mathrm{S}$ (thereafter resuming its easterly course) in the Atlantic sector, contributing to an increase in local productivity (Deacon 1982, Trathan et al. 1997). The other major oceanographic feature in the Indian sector which contributes to a local increase in primary productivity is the Kerguelen Plateau, and also to some extent, the Crozet Islands.

Despite their importance, knowledge of several basic aspects of the ecology of cephalopods is limited, particularly in terms of distribution and trophic ecology (Xavier et al. 1999, Collins \& Rodhouse 2006). One of the main reasons is the limited commercial harvest, which reflects (1) the low number of exploitable squid species, (2) the unpredictability of their stocks, (3) a lack of knowledge of the abundance and distribution of relevant species, and (4) an inability to catch the faster-moving species. Shipbased scientific surveys in the Southern Ocean encounter similar problems, not helped by the low trawl speeds and use of conventional sampling methods (Clarke 1977, Rodhouse 1990, Rodhouse et al. 1996). The available information on diet and trophic relationships is therefore limited largely to 2 common species, Martialia hyadesi and Moroteuthis ingens (Jackson et al. 2007), and otherwise biased towards cephalopods that feed on Antarctic krill Euphausia superba, as these are caught in the same nets (Nemoto et al. 1985, 1988).

An alternative approach to study Southern Ocean cephalopods, and to overcome these sampling problems, is to use seabirds that are cephalopod predators, such as albatrosses (Cherel \& Weimerskirch 1995, Xavier et al. 2003a). In general, albatrosses are an excellent sampling tool for this kind of study because (1) they feed on a great number and diversity of cephalopods (Cherel \& Klages 1998), (2) they breed in high densities on land and so are readily available for diet sampling, (3) they do not fear humans and are therefore easy to work with, (4) they forage over and therefore sample large areas of the ocean, and (5) chicks and adults retain undigested cephalopod beaks in their stomachs for long periods of time. In the present study, we investigated the cephalopod fauna of the south Atlantic and Indian sectors of the Southern Ocean using diet samples collected from wandering albatrosses (Diomedea exulans) breeding at South Georgia, Crozet and Kerguelen islands. The wandering albatross feeds on a large variety of cephalopod species on long foraging trips that during the chick rearing period range from Antarctic to subtropical waters (between $25-64^{\circ} \mathrm{S}$ and about $2800 \mathrm{~km}$ from their colonies) (Imber 1992, Weimerskirch et al. 1993, Xavier et al. 2004). Their patchily-distributed prey are thought to include primarily dead and moribund cephalopods that have floated to the surface post-spawning (Croxall \& Prince 1994, Cherel \& Weimerskirch 1999, Xavier et al. 2003b).

Stable isotope analysis (SIA) of cephalopod beaks gathered from the diet of top predators can provide key ecological information (Cherel \& Hobson 2005, Cherel et al. 2009b). SIA has been used increasingly in the last 2 decades to study the structure of food webs (e.g. Kelly 2000). With this approach, it is possible to infer habitat and trophic level of organisms based, respectively, on the stable isotope ratios of ${ }^{13} \mathrm{C}$ to ${ }^{12} \mathrm{C}\left(\delta^{13} \mathrm{C}\right)$, and ${ }^{15} \mathrm{~N}$ to ${ }^{14} \mathrm{~N}\left(\delta^{15} \mathrm{~N}\right.$ ) (DeNiro \& Epstein 1978, 1981). In the pelagic waters of the Southern Ocean, the carbon isotope ratio ultimately reflects the influence of temperature on photosynthetic activity (Sackett et al. 1974), and $\mathrm{CO}_{2}$ availability, leading to a broad $\delta^{13} \mathrm{C}$ latitudinal gradient in baseline values from equatorial to polar waters, which is propagated through the food chain (Cherel \& Hobson 2007, Jaeger et al. 2010, Quillfeldt et al. 2010). In contrast, the ratio of the stable isotopes of nitrogen can be used to estimate the trophic level of an organism, as there is a stepwise enrichment of ${ }^{15} \mathrm{~N}$ between prey and predators (Montoya 2007).

The objectives of this study were to:

(1) Characterize the habitat and trophic level of the cephalopod fauna of the Atlantic and Indian sectors of the Southern Ocean by analysing the $\delta^{13} \mathrm{C}$ and $\delta^{15} \mathrm{~N}$ values of cephalopod beaks (obtained from the boluses [pellets] and induced regurgitations of wandering albatrosses) as proxies for water mass (latitudinal distribution) and trophic level, respectively;

(2) Compare the trophic niche of these cephalopods based on stable isotope ratios with the few current conventional diet studies;

(3) Assess if each cephalopod species occupies the same niche throughout the Southern Ocean;

(4) Determine if any cephalopods occupy a similar niche to top fish predators.

\section{MATERIALS AND METHODS}

\section{Sampling}

Cephalopod beaks were collected from boluses (from chicks) or induced regurgitations (from adults) of wandering albatrosses during the breeding season at South Georgia ( $54^{\circ} \mathrm{S}, 38^{\circ} \mathrm{W}$; south of the APF), Ker- 
guelen $\left(49^{\circ} \mathrm{S}, 69^{\circ} \mathrm{E}\right.$, in the vicinity of the APF) and Crozet islands $\left(46^{\circ} \mathrm{S}, 51^{\circ} \mathrm{E}\right.$, north of the APF) (Park et al. 1993) (Fig. 1). All samples were collected from September to December 1998, during the latter part of the 8-9 mo chick-rearing period.

At South Georgia, the samples consisted of boluses, which are voluntarily regurgitated by chicks prior to fledging (Xavier et al. 2003a). These comprise the indigestible parts of prey consumed during the winter, from hatching in March or April to fledging in November or December (Xavier et al. 2003b, 2005, Xavier \& Croxall 2007). Diet samples from Crozet and Kerguelen were obtained by induced regurgitation immediately after the chick was fed by one of its parents (Cherel \& Weimerskirch 1999). Samples were frozen at $-20^{\circ} \mathrm{C}$ and subsequently analyzed in the laboratory. The beaks obtained from each sample were cleaned, separated into upper and lower beaks, and counted. When possible, the lower beaks were identified to species level (Xavier \& Cherel 2009) and the lower rostral length (LRL) was measured. Beak identification was confirmed with reference to collections at the British Antarctic Survey and Centre d'Etudes Biologiques de Chizé. Cleaned beaks were kept in $70 \%$ ethanol until isotopic analysis.

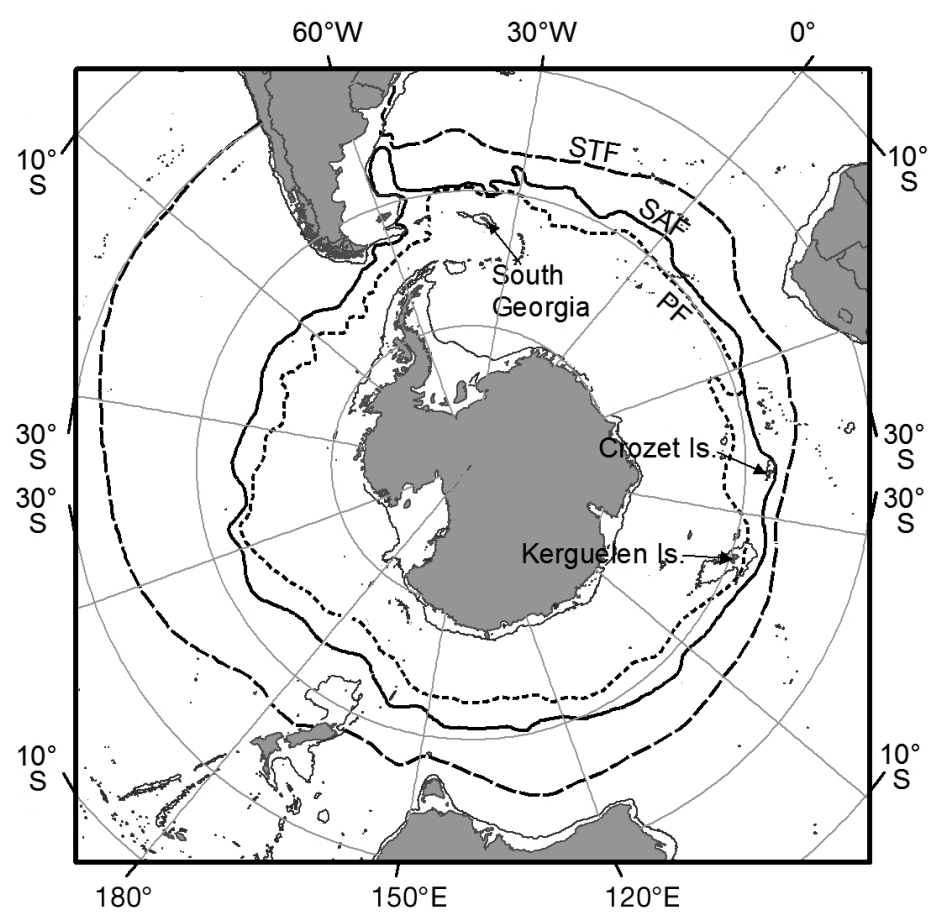

Fig. 1. Map of the Southern Ocean indicating the sampling sites at South Georgia, Crozet and Kerguelen, and the $1000 \mathrm{~m}$ isobath (dark grey line). Antarctic Polar Front (PF), Sub-Antarctic Front (SAF), and Subtropical Front (STF) are the main oceanic fronts (black line patterns)

\section{Stable isotope analysis}

We analyzed the stable isotope ratios of the cephalopod species that were represented by at least 10 lower beaks from one of the island groups. For each species at each island, 10 beaks in good condition were randomly selected, with the exception of Taningia danae (a rare species) with only 5 specimens from Kerguelen, and Haliphron atlanticus (the only octopod species) with 11 specimens from South Georgia. In addition, to assess local ontogenic differences in Histioteuthis atlantica, 2 size-classes of beaks were compared (large and small), which differed in LRL at the same island (for Kerguelen and South Georgia) by a mean of $\sim 2 \mathrm{~mm}$. Prior to the analysis, the whole beaks were dried at $60^{\circ} \mathrm{C}$ and ground into a fine powder; due to an oversight, information on individual beak identity was not retained and so it was not possible to relate LRL to subsequent measurements. Sub-samples (ranging from 0.30$0.55 \mathrm{mg}$ ) of each beak were placed in a tin capsule and the stable isotope values were measured using a Flash EA 1112 Series elemental analyzer coupled online via a Finnigan ConFlo II interface to a Delta V $\mathrm{S}$ mass spectrometer (Thermo Scientific). Analysis of the whole beak provides an integrated, lifetime signal of diet and geographic position, although biased towards more recent periods, when mass increments are greater, rather than to younger ages. The carbon and nitrogen isotope ratios were expressed in delta $(\delta)$ notation relative to Vienna PDB limestone for $\delta^{13} \mathrm{C}$ and atmospheric nitrogen (AIR) for $\delta^{15} \mathrm{~N}$, respectively. Replicate measurements of internal laboratory standards (acetanilide) indicated measurement errors of $<0.15 \%$ for both $\delta^{13} \mathrm{C}(-28.38$ to $-27.73 \%)$ and $\delta^{15} \mathrm{~N}(1.76-2.41 \%)$ values.

\section{Habitat}

Samples with $\delta^{13} \mathrm{C}$ values greater than $-19.5 \%$ were considered to have a subtropical distribution (north of the Subtropical Front), and those with values less than $-22.9 \%$ were considered to be from Antarctic waters (south of the APF) (Cherel \& Hobson 2007, Jaeger et al. 2010); those with intermediate values (between -22.9 and $-19.5 \%$ ) were considered to be of sub-Antarctic origin. Habitat assignments were based on the estimated isotopic positions of APF and STF based on stable isotope ratios in plasma sampled from albatrosses (Jaeger et al. 2010), and blood from penguins (Cherel \& Hobson 2007). These cut-offs may not be as appropriate for cephalopods, 
even though these are depredated by albatrosses, due to differences in trophic levels and in tissue- and species-specific isotopic discrimination factors. Therefore, we adopted a conservative approach, distinguishing Antarctic and subtropical species of cephalopods based on the highest $\delta^{13} \mathrm{C}$ value of the 2 studies for the STF (-19.5\% Eudyptes chrysocome moseleyi blood; Cherel \& Hobson 2007) and the lowest $\delta^{13} \mathrm{C}$ for the APF (-22.9\% Diomedea exulans plasma; Jaeger et al. 2010).

Albatrosses have long foraging distances, and so sample cephalopods over a wide latitudinal range. As the $\delta^{13} \mathrm{C}$ of their squid prey will reflect the point of origin of the squid, differences in foraging ranges of the individual birds per se should not affect our results or conclusions.

\section{Stable isotope niches and isotope metrics}

Corrected standard ellipse areas (SEAc) and Bayesian standard ellipse areas (SEAb) were calculated in order to examine inter- and intra-specific niche size and overlap. Overlap among species pairs was categorized as high (area of overlap $\geq 50 \%$ of the smaller niche area) or low (area of overlap $<50 \%$ of the smaller niche area). Standard ellipse areas were plotted for visualization of the data, using the SIAR package for $\mathrm{R}$ (Parnell et al. 2010, Jackson et al. 2011).

\section{Statistical analyses}

All statistical analyses used a significance level of $\alpha=0.05$, and were performed using R. ANOVAs and $t$-tests were conducted to test for differences in stable isotope ratios in squid beaks collected at the different island groups. Data on Martialia hyadesi were transformed exponentially to fit the assumptions of normal distribution and homoscedasticity. Results of statistical tests are presented as $t$-values, both for the $t$-tests and ANOVAs, as the post hoc test used was the pairwise Tukey HSD. Principal components analysis (PCA) (extracted from the variables average LRL, $\delta^{13} \mathrm{C}$ and $\delta^{15} \mathrm{~N}$ of each group [island populations] covariance matrix), and cluster analysis (CA) (standardized variables, Ward's linkage) were used to assess segregation of various species throughout the Southern Ocean according to the average $\delta^{13} \mathrm{C}$ and $\delta^{15} \mathrm{~N}$ of each group. As beaks from Haliphron atlanticus were eroded, mean LRL (for PCA) was obtained from Xavier et al. 2003b.

\section{RESULTS}

Lower beaks $(n=384)$ of 16 species collected at the 3 island groups (i.e. South Georgia, Crozet and Kerguelen) from the Atlantic and Indian sectors of the Southern Ocean were included in the study. These species comprised $95 \%$ of the total number of lower beaks found in the diet samples of wandering albatrosses (cephalopod component) from all 3 sites (J. Xavier and Y. Cherel unpubl. data).

\section{Beak $\delta^{13} \mathrm{C}$ values}

$\delta^{13} \mathrm{C}$ values in the beaks of individual cephalopods ranged from -25.7 (Kondakovia longimana, South Georgia) to $-17.9 \%$ (Histioteuthis atlantica, Kerguelen) (Table 1, Figs. 2-4). The species displaying highest values was $H$. atlantica (Crozet; mean: $-18.6 \%$ ), and the lowest were found in Batoteuthis skolops (South Georgia; mean: $-24.4 \%$ ). When compared among localities, significantly lower $\delta^{13} \mathrm{C}$ values were found in samples of B. skolops, Galiteuthis glacialis, Histioteuthis eltaninae and $K$. longimana from South Georgia ( $<0.05$ in all cases) (Table 2). The highest $\delta^{13} \mathrm{C}$ values for $H$. atlantica (large size) and Martialia hyadesi were found in samples from Kerguelen. Beak $\delta^{13} \mathrm{C}$ values for Moroteuthis knipovitchi were significantly greater in samples from Crozet than Kerguelen $(p<0.05)$ (Table 2).

\section{Beak $\boldsymbol{\delta}^{15} \mathbf{N}$ values}

Beak $\delta^{15} \mathrm{~N}$ values of individual cephalopods ranged from $2.4 \%$ ( $M$. hyadesi, Crozet) to $13.3 \%$ o (Gonatus antarcticus, South Georgia) (Table 1, Figs. 2-4). The species with highest values for $\delta^{15} \mathrm{~N}$ was Cicloteuthis akimushkini (Crozet: mean: 12.2\%) and the lowest values were for $M$. hyadesi (Crozet; mean: $3.6 \%$ ).

When compared to other sites, significantly higher values of $\delta^{15} \mathrm{~N}$ were observed for $G$. antarcticus and small $H$. atlantica, and lower values for B. skolops at South Georgia ( $p<0.05$ in all cases) (Table 3 ). Higher $\delta^{15} \mathrm{~N}$ values were obtained for Taonius sp. (Clarke) and M. hyadesi from Kerguelen ( $\mathrm{p}<0.05$ in all cases) (Table 3). The lowest mean $\delta^{15} \mathrm{~N}$ value for samples of Taonius sp. B (Voss) was obtained for beaks sampled at Crozet $(\mathrm{p}<0.05)$ (Table 3). Moreover, $\delta^{15} \mathrm{~N}$ values in $H$. eltaninae were higher at South Georgia than at Kerguelen. In contrast, $\delta^{15} \mathrm{~N}$ values in $K$. longimana from Kerguelen were higher than those from South Georgia, whereas those in ?Mastigoteuthis sp. A (Clarke) and 


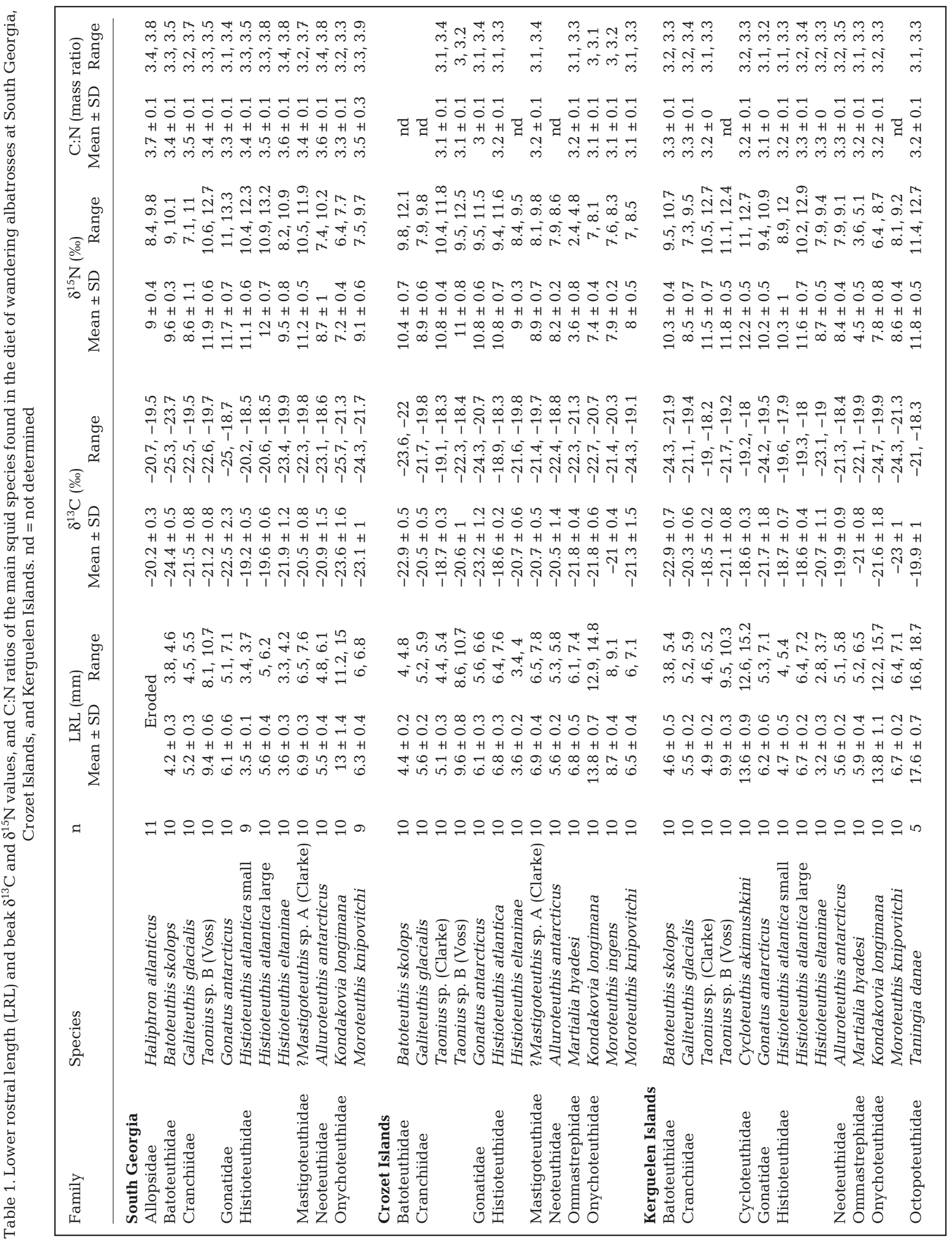




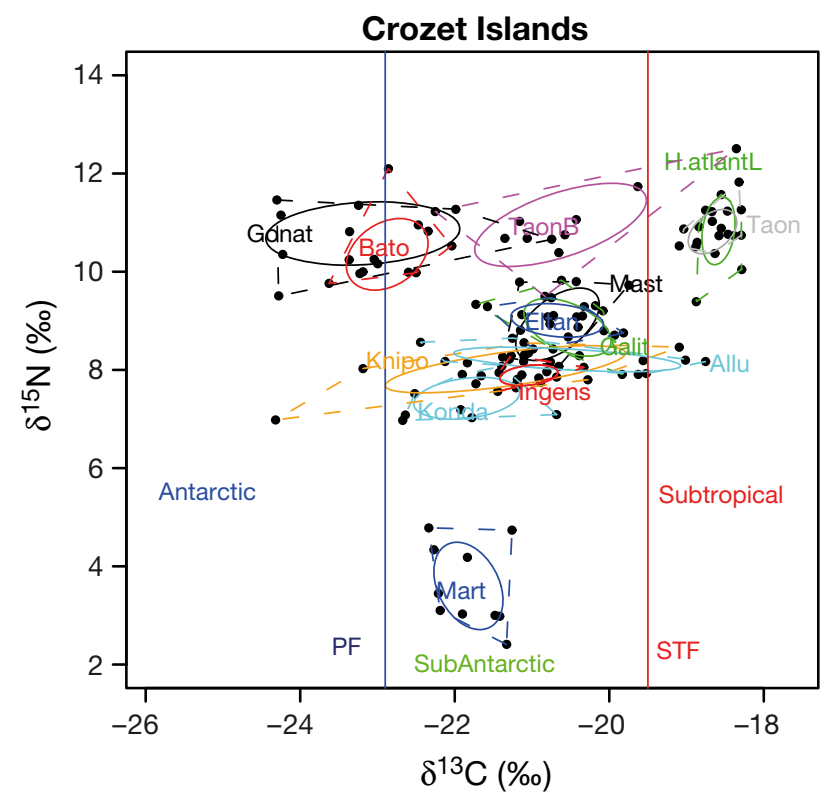

Fig. 2. Plotted distribution of the $\delta^{15} \mathrm{~N}$ and $\delta^{13} \mathrm{C}$ in beaks of the squid species from Crozet Islands. Blue and red vertical lines indicate estimated $\delta^{13} \mathrm{C}$ values corresponding to the Antarctic Polar (PF) and Subtropical fronts (STF), respectively. Bayesian standard ellipse areas are displayed for the various cephalopod species: Allu = Alluroteuthis antarcticus, Bato = Batoteuthis skolops, Eltan = Histioteuthis eltaninae, Galit = Galiteuthis glacialis, Gonat = Gonatus antarcticus, H.atlantL = Histioteuthis atlantica (large), Ingens = Moroteuthis ingens, Knipo = Moroteuthis knipovitchi, Konda = Kondakovia longimana, Mart = Martialia hyadesi, Mast $=$ ?Mastigoteuthis sp. A (Clarke), Taon = Taonius sp. (Clarke), TaonB $=$ Taonius sp. B (Voss)

M. knipovitchi from South Georgia were higher than those found at Crozet ( $p<0.05$ in all cases) (Table 3).

\section{Stable isotope niches and isotope metrics}

The cephalopod fauna of the Southern Ocean was represented by 3 major groups (Figs. 2-5) of species with overlapping niches and 1 outlier: (1) medium $\delta^{15} \mathrm{~N}$ and $\delta^{13} \mathrm{C}$ values $(K$. longimana, $M$. knipovitchi, Moroteuthis ingens, Alluroteuthis antarcticus, G. glacialis, H. eltaninae, ?Mastigoteuthis sp. A (Clarke), Haliphron atlanticus), (2) high $\delta^{15} \mathrm{~N}$ and average $\delta^{13} \mathrm{C}$ values (B. skolops, G. antarcticus, Taonius sp. B (Voss) and Taningia danae), and (3) high $\delta^{15} \mathrm{~N}$ and $\delta^{13} \mathrm{C}$ values (Histioteuthis atlantica, Taonius sp. [Clarke] and C. akimushkini), and the outlier M. hyadesi (extremely low $\delta^{15} \mathrm{~N}$ ) (Figs. 3-5). The first group can be further divided into 2 sub-groups: (1) species with lower $\delta^{13} \mathrm{C}$ values that show low overlap ( $K$. longimana, M. knipovitchi), and (2) species with higher $\delta^{13} \mathrm{C}$ values and high levels of overlap ( $M$. ingens, $A$.

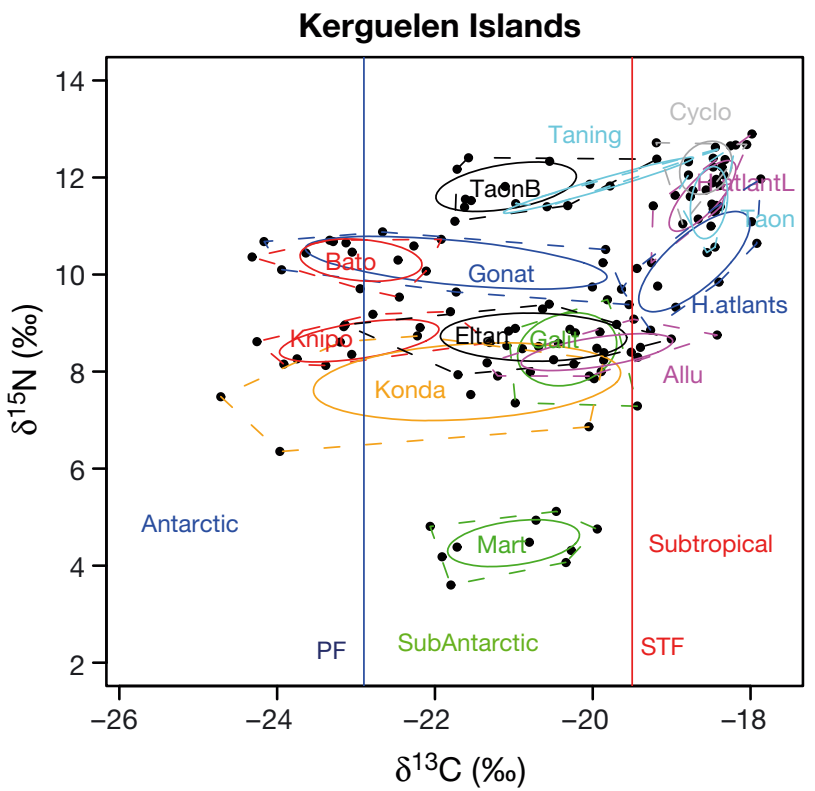

Fig. 3. Plotted distribution of the $\delta^{15} \mathrm{~N}$ and $\delta^{13} \mathrm{C}$ in beaks of the squid species from Kerguelen. Blue and red vertical lines indicate estimated $\delta^{13} \mathrm{C}$ values corresponding to the Antarctic Polar (PF) and Subtropical fronts (STF), respectively. Bayesian standard ellipse areas are displayed for the various cephalopod species: Allu = Alluroteuthis antarcticus, Bato $=$ Batoteuthis skolops, Cyclo = Cycloteuthis akimushkini, Eltan = Histioteuthis eltaninae, Galit = Galiteuthis glacialis, Gonat $=$ Gonatus antarcticus, H.atlantL $=$ Histioteuthis atlantica (large), H.atlants = Histioteuthis atlantica (small), Knipo = Moroteuthis knipovitchi, Konda = Kondakovia longimana, Mart = Martialia hyadesi, Taning $=$ Taningia danae, Taon = Taonius sp. $($ Clarke $)$, TaonB = Taonius sp. B (Voss)

antarcticus, G. glacialis, H. eltaninae, ?Mastigoteuthis sp. A (Clarke), Haliphron atlanticus). Species niche size (SEAc) varied from $<0.5$ (e.g. M. ingens $=0.2, H$. atlanticus $=0.3$ ) to $>4$ (e.g. G. antarcticus of South Georgia $=4.5, K$. longimana of Kerguelen $=4.8$ ).

The degree of overlap in isotopic niche differed among the 3 island groups depending on the species, especially comparing between South Georgia and the other sampling sites (Crozet and Kerguelen Islands). Isotopic niches of specimens from Crozet showed either a low overlap with the same species at the other 2 sites, a high overlap between Crozet and Kerguelen (B. skolops, $H$. eltaninae, K. longimana, Histioteuthis atlantica large), or a high overlap between Kerguelen and South Georgia ( $M$. knipovitchi, Taonius sp. B [Voss]). Regardless of the overlap, the overall isotopic niche sizes, however, seemed to be similar across sites. The exceptions were a few species at Crozet which had isotopic niches that were smaller than at the other island groups ( $K$. longimana and $H$. eltaninae). 


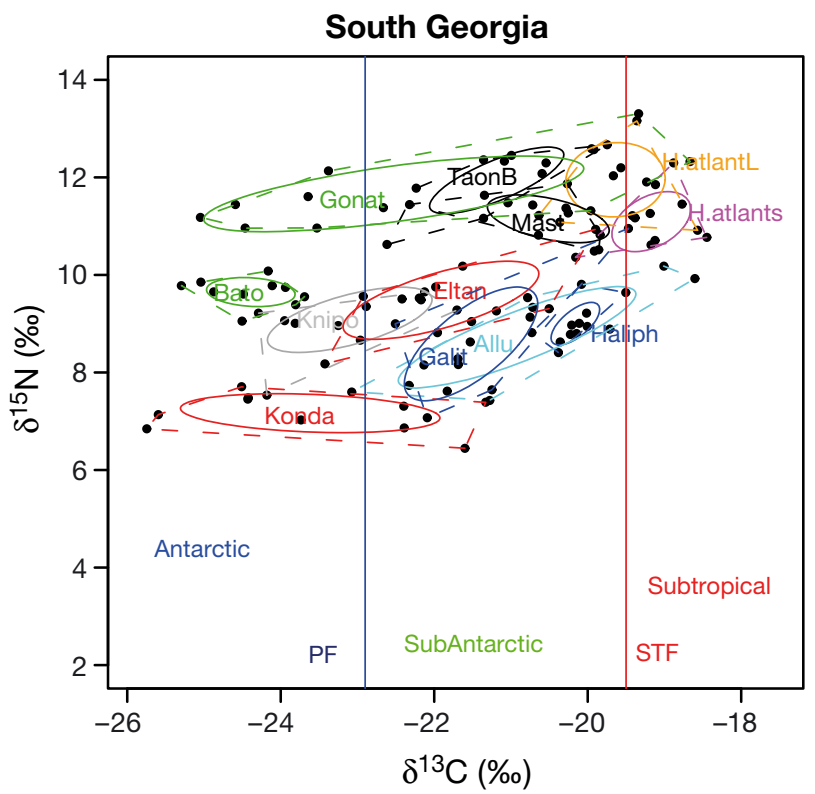

Fig. 4. Plotted distribution of the $\delta^{15} \mathrm{~N}$ and $\delta^{13} \mathrm{C}$ in beaks of the squid species from South Georgia. Blue and red vertical lines indicate estimated $\delta^{13} \mathrm{C}$ values corresponding to the Antarctic Polar (PF) and Subtropical fronts (STF), respectively. Bayesian standard ellipse areas are displayed for the various cephalopod species: Allu = Alluroteuthis antarcticus, Bato = Batoteuthis skolops, Eltan = Histioteuthis eltaninae, Galit $=$ Galiteuthis glacialis, Gonat = Gonatus antarcticus, Haliph = Haliphron atlanticus, H.atlantL = Histioteuthis atlantica (large), H.atlants = Histioteuthis atlantica (small), Knipo = Moroteuthis knipovitchi, Konda $=$ Kondakovia longimana, Mast $=$ ?Mastigoteuthis sp. A (Clarke), TaonB = Taonius sp. (Clarke)

\section{Multivariate analysis}

The first 2 principal components (PC) explained $>89 \%$ of the overall variance (Fig. 6). Mean LRL loaded heavily and positively on the first axis (PC1), and mean $\delta^{15} \mathrm{~N}$ (and to a lesser extent mean $\delta^{13} \mathrm{C}$ ) loaded heavily and positively on the second axis (PC2) (Fig. 6). Large species tended to be associated with a positive score on PC1, whereas subtropical species tended to be associated with a positive score on PC2 (Fig. 7). The 2 dendrograms produced by the CA (Fig. 8), showed 2 different aggregation patterns according to the SI ratio used: a clear separation near the top (root) between species with high and low $\delta^{15} \mathrm{~N}$ (2 groups), and 3 separate groups of species based on $\delta^{13} \mathrm{C}$ values.

\section{DISCUSSION}

The results indicate that $\delta^{13} \mathrm{C}$ tended to be lower, $\delta^{15} \mathrm{~N}$ tended to be higher, and that both ratios showed higher variance in the lower beaks of cephalopods from South Georgia compared to conspecifics in the Indian sector of the Southern Ocean. Based on the stable isotope data, the cephalopods in the diet of the wandering albatross were from 3 water masses (Antarctic, sub-Antarctic and subtropical), and spanned over 3 trophic levels from Martialia hyadesi to Gonatus antarcticus (based on $\delta^{15} \mathrm{~N}$ range divided by 3.3 , where 3.3 equals the stepwise enrichment in $\delta^{15} \mathrm{~N}$ from prey to predator/consumer [Wada et al. 1987]).

Table 2. Tests (a posteriori) comparing $\delta^{13} \mathrm{C}$ values of the squid sampled at South Georgia (SG), Crozet (CRZ) and Kerguelen $(\mathrm{KRG})$. Tests: $\mathrm{A}=\mathrm{ANOVA}$, Tukey tests $(2 \mathrm{df}) ; \mathrm{T}=t$-test $(1 \mathrm{df}) ; \mathrm{ns}=$ non-significant; blank cell = non-existent pair

\begin{tabular}{|c|c|c|c|c|c|c|c|c|}
\hline \multirow{2}{*}{ Family } & \multirow[t]{2}{*}{ Species } & \multirow[t]{2}{*}{ Test } & \multicolumn{2}{|c|}{$\mathrm{SG}-\mathrm{CRZ}$} & \multicolumn{2}{|c|}{ CRZ - KRG } & \multicolumn{2}{|c|}{$\mathrm{KRG}-\mathrm{SG}$} \\
\hline & & & Test value & $\mathrm{p}$ & Test value & $\mathrm{p}$ & Test value & $\mathrm{p}$ \\
\hline Batoteuthidae & Batoteuthis skolops & A & -1.52 & $<0.01$ & 0.06 & ns & 1.45 & $<0.01$ \\
\hline \multirow[t]{3}{*}{ Cranchiidae } & Galiteuthis glacialis & A & -0.98 & $<0.01$ & -0.22 & ns & 1.2 & $<0.01$ \\
\hline & Taonius sp. (Clarke) & $\mathrm{T}$ & & & -1.16 & ns & & \\
\hline & Taonius sp. B (Voss) & $\mathrm{A}$ & -0.56 & ns & 0.47 & ns & 0.09 & ns \\
\hline Gonatidae & Gonatus antarcticus & A & 0.66 & ns & -1.46 & ns & 0.8 & ns \\
\hline \multirow[t]{4}{*}{ Histioteuthidae } & Histioteuthis atlantica & $\mathrm{A}$ & -0.83 & $<0.01$ & 0.07 & ns & 0.76 & $<0.01$ \\
\hline & Histioteuthis atlantica small & $\mathrm{T}$ & & & & & 1.71 & ns \\
\hline & Histioteuthis atlantica large & $\mathrm{T}$ & & & & & -4.46 & $<0.01$ \\
\hline & Histioteuthis eltaninae & $\mathrm{A}$ & -1.24 & 0.02 & 0.08 & ns & 1.16 & 0.03 \\
\hline Mastigoteuthidae & ?Mastigoteuthis sp. A (Clarke) & $\mathrm{T}$ & -0.55 & ns & & & & \\
\hline Neoteuthidae & Alluroteuthis antarcticus & A & -0.38 & ns & -0.6 & ns & 0.97 & ns \\
\hline Ommastrephidae & Martialia hyadesi & $\mathrm{T}$ & & & -2.9 & $<0.01$ & & \\
\hline \multirow[t]{2}{*}{ Onychoteuthidae } & Kondakovia longimana & A & -1.77 & 0.03 & -0.25 & ns & 2.02 & 0.01 \\
\hline & Moroteuthis knipovitchi & $\mathrm{A}$ & -1.76 & $<0.01$ & 1.62 & 0.01 & 0.14 & $\mathrm{~ns}$ \\
\hline
\end{tabular}


Table 3. Tests (a posteriori) comparing $\delta^{15} \mathrm{~N}$ values of the squid sampled at South Georgia (SG), Crozet (CRZ) and Kerguelen $(\mathrm{KRG})$. Tests: $\mathrm{A}=\mathrm{ANOVA}$, Tukey tests $(2 \mathrm{df}) ; \mathrm{T}=t$-test $(1 \mathrm{df}) ; \mathrm{T}(\mathrm{EXP})=t$-test on exponentially transformed variables $(1 \mathrm{df}) ;$ $\mathrm{ns}=$ non-significant; blank cell = non-existent pair

\begin{tabular}{|c|c|c|c|c|c|c|c|c|}
\hline \multirow[t]{2}{*}{ Family } & \multirow[t]{2}{*}{ Species } & \multirow[t]{2}{*}{ Test } & \multicolumn{2}{|c|}{$\mathrm{SG}-\mathrm{CRZ}$} & \multicolumn{2}{|c|}{ CRZ - KRG } & \multicolumn{2}{|c|}{$\mathrm{KRG}-\mathrm{SG}$} \\
\hline & & & Test value & $\mathrm{p}$ & Test value & $\mathrm{p}$ & Test value & $\mathrm{p}$ \\
\hline Batoteuthidae & Batoteuthis skolops & A & -0.7 & $<0.01$ & 0.06 & ns & 0.65 & 0.02 \\
\hline Cranchiidae & $\begin{array}{l}\text { Galiteuthis glacialis } \\
\text { Taonius sp. (Clarke) } \\
\text { Taonius sp. B (Voss) }\end{array}$ & $\begin{array}{l}\mathrm{A} \\
\mathrm{T} \\
\mathrm{A}\end{array}$ & $\begin{array}{r}-0.28 \\
0.99\end{array}$ & $\begin{array}{c}\text { ns } \\
<0.01\end{array}$ & $\begin{array}{c}0.41 \\
-2.56 \\
-0.86\end{array}$ & $\begin{array}{c}\mathrm{ns} \\
0.02 \\
0.02\end{array}$ & $\begin{array}{l}-0.13 \\
-0.13\end{array}$ & $\begin{array}{l}\text { ns } \\
\text { ns }\end{array}$ \\
\hline Gonatidae & Gonatus antarcticus & A & 0.88 & 0.01 & 0.53 & ns & -1.42 & $<0.01$ \\
\hline Histioteuthidae & $\begin{array}{l}\text { Histioteuthis atlantica } \\
\text { Histioteuthis atlantica small } \\
\text { Histioteuthis atlantica large } \\
\text { Histioteuthis eltaninae }\end{array}$ & $\begin{array}{l}\mathrm{A} \\
\mathrm{T} \\
\mathrm{T} \\
\mathrm{A}\end{array}$ & 0.71 & ns & -0.11 & ns & $\begin{array}{c}-0.6 \\
-2.22 \\
1.05 \\
-0.77\end{array}$ & $\begin{array}{c}\text { ns } \\
0.04 \\
\text { ns } \\
0.01\end{array}$ \\
\hline Mastigoteuthidae & ?Mastigoteuthis sp. A (Clarke) & $\mathrm{T}$ & -8.42 & $<0.01$ & & & & \\
\hline Neoteuthidae & Alluroteuthis antarcticus & $\mathrm{A}$ & 0.51 & ns & -0.19 & ns & -0.32 & ns \\
\hline Ommastrephidae & Martialia hyadesi & $\mathrm{T}(\mathrm{EXP})$ & & & -2.46 & 0.02 & & \\
\hline Onychoteuthidae & $\begin{array}{l}\text { Kondakovia longimana } \\
\text { Moroteuthis knipovitchi }\end{array}$ & $\begin{array}{l}\mathrm{A} \\
\mathrm{A}\end{array}$ & $\begin{array}{c}-0.26 \\
1.07\end{array}$ & $\begin{array}{c}\mathrm{ns} \\
<0.01\end{array}$ & $\begin{array}{l}-0.37 \\
-0.62\end{array}$ & $\begin{array}{c}\mathrm{ns} \\
0.02\end{array}$ & $\begin{array}{c}0.63 \\
-0.44\end{array}$ & $\begin{array}{c}0.03 \\
\mathrm{~ns}\end{array}$ \\
\hline
\end{tabular}

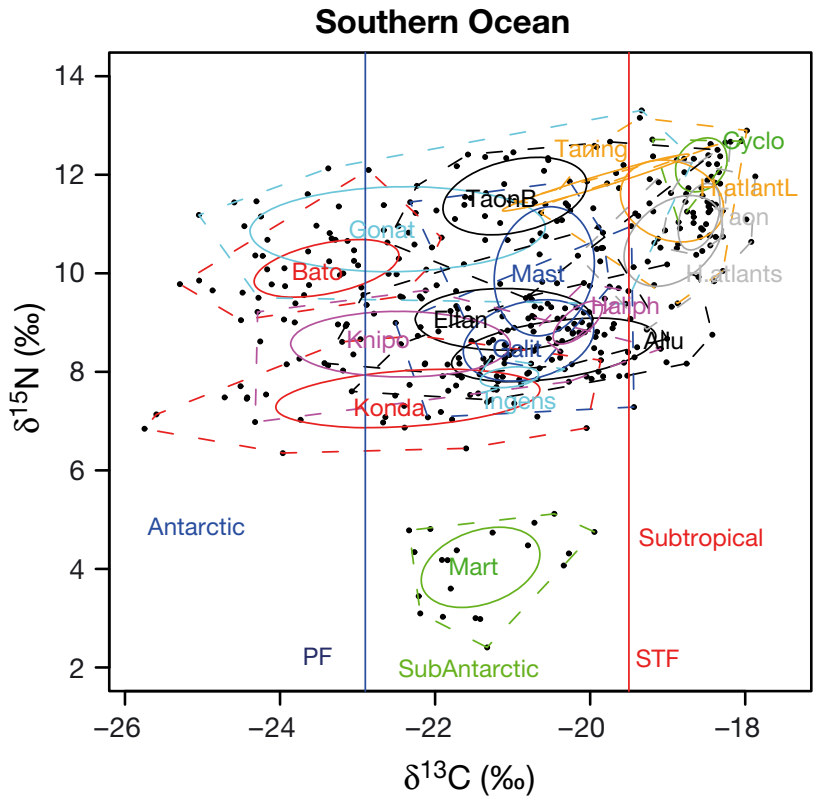

Fig. 5. Plotted distribution of the $\delta^{15} \mathrm{~N}$ and $\delta^{13} \mathrm{C}$ in beaks of the squid species from the Southern Ocean. Blue and red vertical lines indicate estimated $\delta^{13} \mathrm{C}$ values corresponding to the Antarctic Polar (PF) and Subtropical fronts (STF), respectively. Bayesian standard ellipse areas are displayed for the various cephalopod species: Allu = Alluroteuthis antarcticus, Bato = Batoteuthis skolops, Cyclo = Cycloteuthis akimush kini, Eltan = Histioteuthis eltaninae, Galit = Galiteuthis glacialis, Gonat $=$ Gonatus antarcticus, Haliph $=$ Haliphron at lanticus, H.atlantL = Histioteuthis atlantica (large), H.atlants = Histioteuthis atlantica (small), Ingens = Moroteuthis ingens, Knipo = Moroteuthis knipovitchi, Konda = Kondakovia longimana, Mart = Martialia hyadesi, Mast $=$ ? Mastigoteuthis sp. A (Clarke), Taning = Taningia danae, Taon = Taonius sp. (Clarke), TaonB = Taonius sp.B (Voss)
The cephalopod community appeared to consist of 3 separate assemblages (average $\delta^{15} \mathrm{~N}$ and $\delta^{13} \mathrm{C}$, high $\delta^{15} \mathrm{~N}$ and low $\delta^{13} \mathrm{C}$, high $\delta^{15} \mathrm{~N}$ and $\delta^{13} \mathrm{C}$ ) and one outlier, M. hyadesi. Furthermore, the cephalopod community showed significant intra-specific differences in their isotopic niches associated with the island group.

\section{Beak $\delta^{13} \mathrm{C}$ values and biogeography}

The low $\delta^{13} \mathrm{C}$ found in squid beaks collected at South Georgia may be due to the higher latitude of the sampling location compared to Crozet and Ker-

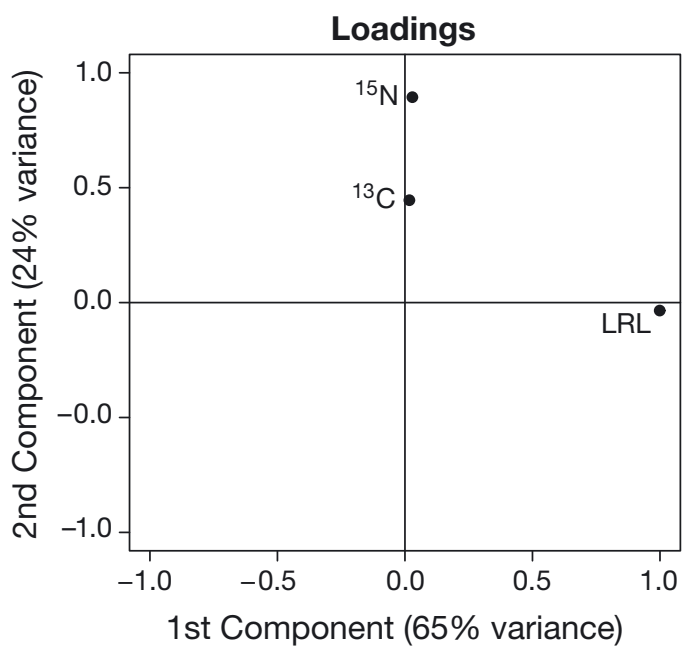

Fig. 6. Loadings on the first 2 principal components (PC1 and $\mathrm{PC} 2$ ) for the mean values of variables lower rostral length (LRL), $\delta^{13} \mathrm{C}$ and $\delta^{15} \mathrm{~N}$ 
Fig. 7. Individual principal component scores (from PC1 and PC2 displayed in Fig. 6) of each sample area (SG = South Georgia, CRZ = Crozet Islands, KRG = Kerguelen Islands) and squid species: - = Alluroteuthis antarcticus, $\cdot=$ Batoteuthis skolops, $\bullet=$ Histioteuthis eltaninae, $\bullet=$ Galiteuthis glacialis, $\bullet=$ Gonatus antarcticus, $\square=$ Histioteuthis atlantica (large), = Histioteuthis atlantica (small), $\circ=$ Moroteuthis ingens, • = Moroteuthis knipovitchi, $\bigcirc=$ Kondakovia longimana, $\circ=$ Martialia hyadesi, $-=$ ?Mastigoteuthis sp. A (Clarke), ○= Taonius sp. (Clarke), o= Taonius sp. B (Voss), - = Cycloteuthis akimushkini, $\bigcirc=$ Taningia danae, $\bigcirc=$ Haliphron atlanticus

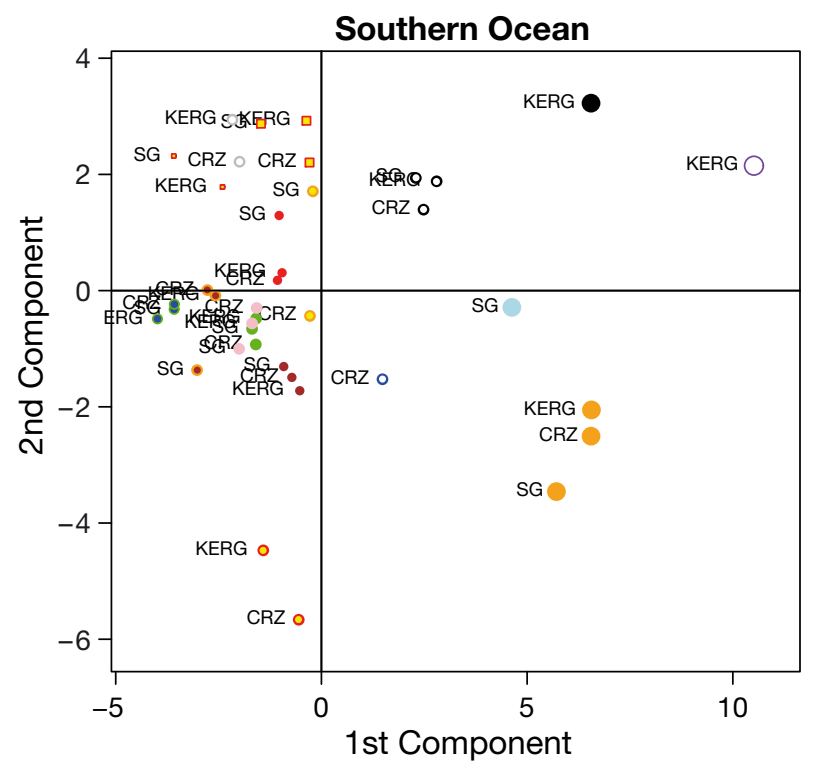

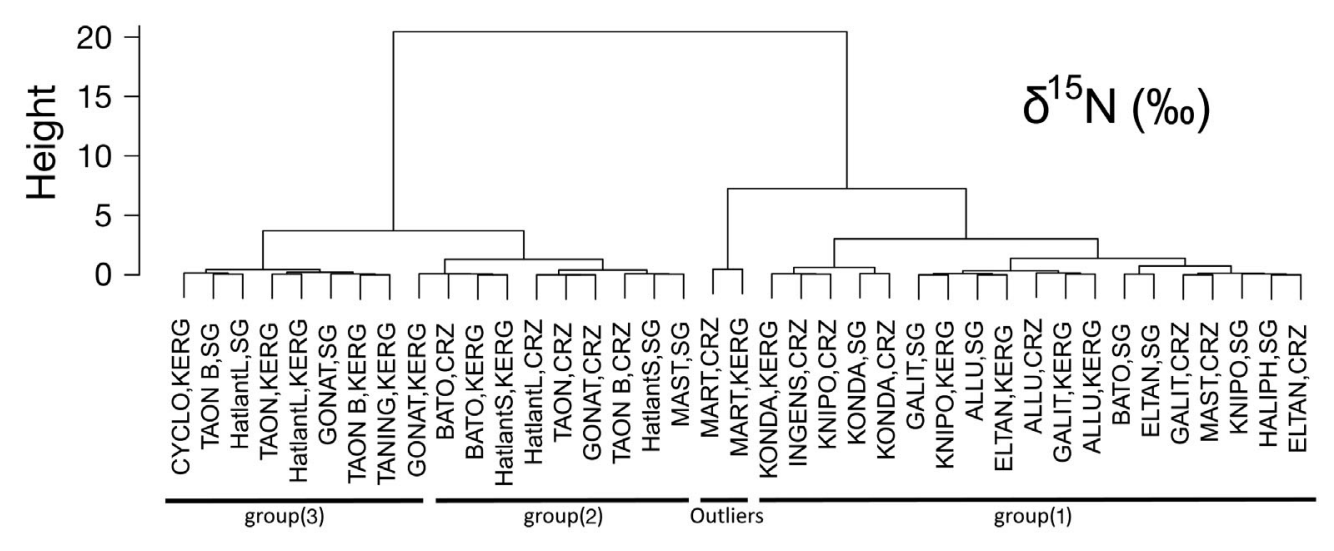

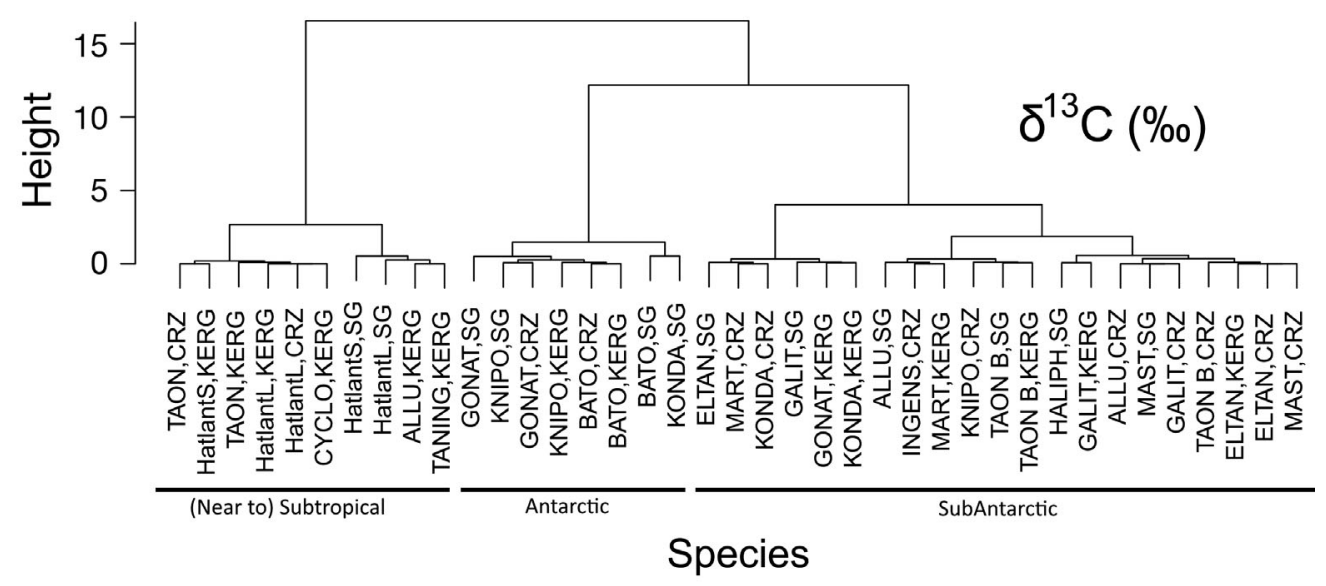

Fig. 8. Dendrograms produced by Cluster Analysis (using standardized variables and Ward's linkage method) showing aggregations of species and sample areas $\left(\mathrm{SG}=\right.$ South Georgia, CRZ $=$ Crozet Islands, KERG $=$ Kerguelen) based on $\delta^{15} \mathrm{~N}$ (upper panel) and $\delta^{13} \mathrm{C}$ (lower panel) data, and their functional classification (below each dendrogram). ALLU = Alluroteuthis antarcticus, BATO = Batoteuthis skolops, CYCLO = Cycloteuthis akimushkini, ELTAN = Histioteuthis eltaninae, GALIT = Galiteuthis glacialis, GONAT = Gonatus antarcticus, HALIPH = Haliphron atlanticus, HatlantL = Histioteuthis atlantica (large), HatlantS = Histioteuthis atlantica (small), INGENS = Moroteuthis ingens, KNIPO = Moroteuthis knipovitchi, KONDA = Kondakovia longimana, MART = Martialia hyadesi, MAST $=$ ? Mastigoteuthis sp. A (Clarke), TANING = Taningia danae, TAON = Taonius sp.

(Clarke), TAON B = Taonius sp. B (Voss) 


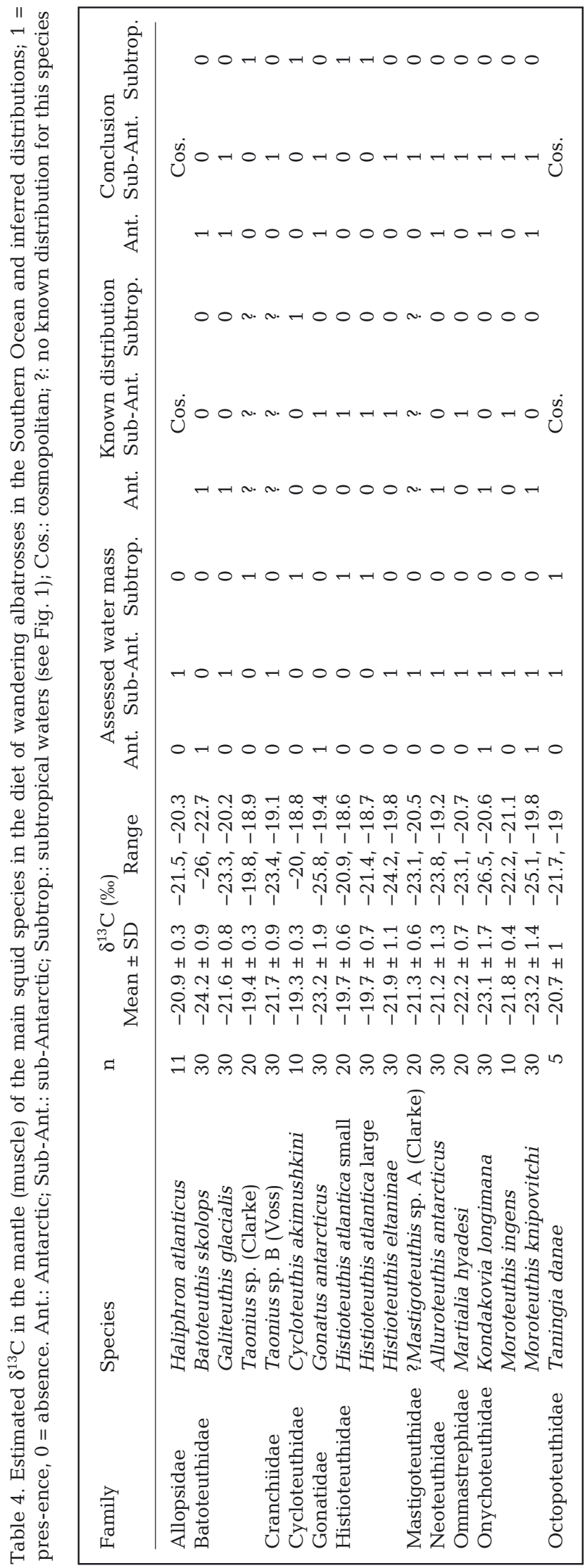

guelen (south vs. north of the APF, respectively). Also, some squid from higher latitudes (e.g. Moroteuthis knipovitchi, Table 4) in Kerguelen showed lower $\delta^{13} \mathrm{C}$ values than the same species from the lower latitude site at Crozet. However, this was not true in all species (e.g. M. hyadesi and Histioteuthis atlantica, Table 4), possibly due to the higher baseline $\delta^{13} \mathrm{C}$ of the Kerguelen Plateau (Trull et al. 2008).

To enable comparison with other studies, the mean isotope ratio in soft tissue was estimated, by subtracting $0.75 \%$ from the $\delta^{13} \mathrm{C}$ values measured in the beaks (Hobson \& Cherel 2006). These corrected values and their assigned distribution (Cherel \& Hobson 2007, Jaeger et al. 2010) was then contrasted with previous assessments (Xavier et al. 1999, Collins \& Rodhouse 2006, Xavier \& Cherel 2009) (Table 4). Cephalopod species that were previously considered to live at high latitudes (according to Xavier et al. 1999, our Table 4) - Batoteuthis skolops, Kondakovia longimana and $M$. knipovitchi-had the lowest mean $\delta^{13} \mathrm{C}$ (and high standard deviations, except for $B$. skolops). Surprisingly, G. antarcticus also displayed very low values, despite previous evidence that it is mostly distributed in northern sub-Antarctic waters (Xavier et al. 1999, Collins \& Rodhouse 2006). The high standard deviation in $\delta^{13} \mathrm{C}$ recorded in $K$. longimana and $M$. knipovitchi, and low mean values in G. antarcticus can be explained by a broader distribution of these species, including north and south of the APF, in agreement with Cherel \& Weimerskirch (1999). Therefore, these 3 species ( $K$. longimana, $M$. knipovitchi and G. antarcticus) are distributed across the APF (both in Antarctic and sub-Antarctic waters), whereas B. skolops is found exclusively in Antarctic waters (Fig. 5, Table 4). The so-called subtropical species that were sampled (Taonius sp. [Clarke], Taonius sp. B [Voss 1980], Cycloteuthis akimushkini and Histioteuthis atlantica [Voss et al. 1998]) (Table 4), were those with the highest $\delta^{13} \mathrm{C}$, indicating distributions that are around and to the north of the STF (Fig. 5, Table 4).

$\delta^{13} \mathrm{C}$ values typical of sub-Antarctic waters were obtained for numerous species (Haliphron atlanticus, Taningia danae, M. ingens, M. hyadesi, H. eltaninae, Taonius sp. B [Voss], Alluroteuthis antarcticus, Galiteuthis glacialis and ?Mastigoteuthis sp. A [Clarke]) (Fig. 5, Table 4). Collins \& Rodhouse (2006) and Xavier et al. (1999) considered that A. antarcticus and G. glacialis live primarily in Antarctic waters; however, our isotopic data suggest that some individuals inhabit sub-Antarctic waters (Table 4).

Furthermore, clustering of species based on $\delta^{13} \mathrm{C}$ (Fig. 8), supports the biogeographic assessment dis- 
cussed above. The 3 clusters distinguished in that analysis correspond unequivocally to cephalopods originating from Antarctic, sub-Antarctic or (near to) subtropical waters.

\section{Beak $\delta^{15} \mathrm{~N}$ values and trophic relationships}

Several cephalopod species showed higher $\delta^{15} \mathrm{~N}$ in samples from South Georgia than from the other island groups (especially Crozet), which suggests that either squid at South Georgia have different feeding preferences (higher trophic level) from those in the Indian Sector, or there are regional differences in primary productivity that lead to differences in $\delta^{15} \mathrm{~N}$ baselines between regions, relating to the relative dominance of eukaryote vs. prokaryote (autotrophic) production (Fawcett et al. 2011). Regardless, the present study largely confirms previous findings based on stable isotope analysis for most of the studied species (Cherel \& Hobson 2005, Cherel et al. 2008), with the exception of $K$. longimana and $G$. antarcticus, for which $\delta^{15} \mathrm{~N}$ values were higher than those recorded previously (Wada et al. 1987, Cherel \& Hobson 2005, Cherel et al. 2008).

The distribution of $\delta^{15} \mathrm{~N}$ in the different species suggested 3 distinct groups and one outlier ( $M$. hyadesi). The 3 groups were: (1) the onychoteuthid squids (with the lowest $\delta^{15} \mathrm{~N}$ values, especially $K$. longimana) plus Haliphron atlanticus, $H$. eltaninae, G. glacialis; (2) ?Mastigoteuthis sp. A (Clarke), B. skolops, G. antarcticus, Taonius sp. B (Voss) and Taningia danae; and finally (3) the subtropical squid C. akimushkini, Histioteuthis atlantica and Taonius sp. (Clarke). This classification is confirmed by the multivariate analysis (Figs. 7 \& 8), which distinguished 2 large, well-defined groups (with $M$. hyadesi and group (1) in the first, and groups (2) and (3) in the second) (Fig. 8).

By correcting the measured $\delta^{15} \mathrm{~N}$ values for beaks to provide estimates for soft tissue (by adding $4.86 \%$; Hobson \& Cherel 2006), and comparing these results with muscle samples collected in previous studies in the same regions (Tables $5 \& 6$ ), it is possible to infer potential prey. However, this is with the caveat that these correction factors may not be appropriate for all species. Nevertheless, the most probable niches occupied by these animals are as follows. M. hyadesi is known to feed mainly on hyperiid amphipods and myctophid fish, and to a lesser extent on cephalopods, including a degree of cannibalism (Rodhouse et al. 1992). Since myctophid fish tend to be at a similar or higher trophic level based on nitrogen isotope ratios (Tables 5 \& 6) (Cherel et al. 2008), it seems that $M$. hyadesi feeds on myctophids in lower quantities than previously suggested, at least in the southern Indian Ocean. $K$. longimana presented very low $\delta^{15} \mathrm{~N}$ values (and high LRL; Fig. 7), but not low enough to be entirely dependent on euphausiids (Table 5) (Nemoto et al. 1985, 1988), and thus its diet seems likely to include some prey with low $\delta^{15} \mathrm{~N}$ values such as crustaceans and myctophid fish (Table 6) (Kaehler

Table 5. Estimated $\delta^{15} \mathrm{~N}$ values in mantle (muscle) of the main squid species in the diet of wandering albatrosses at South Georgia, Crozet and Kerguelen

\begin{tabular}{|c|c|c|c|c|c|c|c|c|c|c|}
\hline \multirow[t]{2}{*}{ Family } & \multirow[t]{2}{*}{ Species } & \multicolumn{3}{|c|}{ South Georgia } & \multicolumn{3}{|c|}{ Crozet Islands -} & \multicolumn{3}{|c|}{ —Kerguelen Islands_- } \\
\hline & & $\mathrm{n}$ & Mean $\pm \mathrm{SD}$ & Range & $\mathrm{n}$ & Mean $\pm \mathrm{SD}$ & Range & $\mathrm{n}$ & Mean $\pm \mathrm{SD}$ & Range \\
\hline Allopsidae & Haliphron atlanticus & 11 & $13.9 \pm 0.4$ & $13.3-14.7$ & 0 & & & 0 & & \\
\hline Batoteuthidae & Batoteuthis skolops & 10 & $14.5 \pm 0.3$ & $13.9-15$ & 10 & $15.2 \pm 0.7$ & $14.7-17$ & 10 & $15.2 \pm 0.4$ & $14.4-15.6$ \\
\hline \multirow[t]{3}{*}{ Cranchiidae } & Galiteuthis glacialis & 10 & $13.5 \pm 1.1$ & $12-15.9$ & 10 & $13.8 \pm 0.6$ & $12.8-14.7$ & 10 & $13.3 \pm 0.7$ & $12.2-14.4$ \\
\hline & Taonius sp. (Clarke) & 0 & & & 10 & $15.7 \pm 0.4$ & $15.3-16.7$ & 10 & $16.4 \pm 0.7$ & $15.3-17.6$ \\
\hline & Taonius sp. B (Voss) & 10 & $16.8 \pm 0.6$ & $15.5-17.6$ & 10 & $15.8 \pm 0.8$ & $14.4-17.4$ & 10 & $16.7 \pm 0.5$ & $16-17.3$ \\
\hline Cycloteuthidae & Cycloteuthis akimushkini & 0 & & & 0 & & & 10 & $17.1 \pm 0.5$ & $15.9-17.6$ \\
\hline Gonatidae & Gonatus antarcticus & 10 & $16.6 \pm 0.7$ & $15.9-18.2$ & 10 & $15.7 \pm 0.6$ & $14.4-16.4$ & 10 & $15.1 \pm 0.5$ & $14.3-15.8$ \\
\hline \multirow[t]{3}{*}{ Histioteuthidae } & Histioteuthis atlantica small & 9 & $16 \pm 0.6$ & $15.3-17.2$ & 0 & & & 10 & $15.2 \pm 1$ & $13.7-16.9$ \\
\hline & Histioteuthis atlantica Large & 10 & $16.8 \pm 0.7$ & $15.8-18.1$ & 10 & $15.7 \pm 0.7$ & $14.3-16.5$ & 10 & $16.5 \pm 0.7$ & $15.1-17.8$ \\
\hline & Histioteuthis eltaninae & 10 & $14.4 \pm 0.8$ & $13.1-15.8$ & 10 & $13.9 \pm 0.3$ & $13.3-14.4$ & 10 & $13.6 \pm 0.5$ & $12.8-14.3$ \\
\hline Mastigoteuthidae & ?Mastigoteuthis sp. A (Clarke) & 10 & $16 \pm 0.5$ & $15.4-16.8$ & 10 & $13.8 \pm 0.7$ & $13-14.7$ & 0 & & \\
\hline Neoteuthidae & Alluroteuthis antarcticus & 10 & $13.6 \pm 1$ & $12.3-15.1$ & 10 & $13.1 \pm 0.2$ & $12.8-13.5$ & 10 & $13.3 \pm 0.4$ & $12.8-14$ \\
\hline Ommastrephidae & Martialia hyadesi & 0 & & & 10 & $8.5 \pm 0.8$ & $7.3-9.7$ & 10 & $9.4 \pm 0.5$ & $8.5-10$ \\
\hline \multirow[t]{3}{*}{ Onychoteuthidae } & Kondakovia longimana & 10 & $12.1 \pm 0.4$ & $11.3-12.6$ & 10 & $12.3 \pm 0.4$ & 11.9-13 & 10 & $12.7 \pm 0.8$ & $11.2-13.6$ \\
\hline & Moroteuthis ingens & 0 & & & 10 & $12.8 \pm 0.2$ & $12.5-13.2$ & 0 & & \\
\hline & Moroteuthis knipovitchi & 9 & $14 \pm 0.6$ & $12.4-14.6$ & 10 & $12.9 \pm 0.5$ & $11.9-13.4$ & 10 & $13.5 \pm 0.4$ & $13-14.1$ \\
\hline Octopoteuthidae & Taningia danae & 0 & & & 0 & & & 5 & $16.7 \pm 0.5$ & $16.3-17.5$ \\
\hline
\end{tabular}


Table 6. Trophic level and $\delta^{15} \mathrm{~N}$ of squid, crustacea and marine vertebrates sampled in previous studies in the Southern Ocean

\begin{tabular}{|c|c|c|c|c|}
\hline & $\begin{array}{c}\delta^{15} \mathrm{~N}(\%) \\
\text { Mean } \pm \text { SD/Range }\end{array}$ & $\begin{array}{c}\text { TL } \\
\text { Mean } \pm \text { SD/Range }\end{array}$ & Location & Reference \\
\hline \multicolumn{5}{|l|}{ Amphipods } \\
\hline \multirow[t]{2}{*}{ Themisto gaudichaudii } & $5.0 \pm 1.2$ & 2.5 & Kerguelen & Cherel et al. (2008) \\
\hline & $5.1 \pm 1.3$ & $2.8 \pm 0.4$ & Scotia Sea & Stowasser et al. (2012) \\
\hline \multicolumn{5}{|l|}{ Euphausiids } \\
\hline \multirow[t]{2}{*}{ Euphausia vallentini } & $5.4 \pm 0.8$ & 2.6 & Kerguelen & Cherel et al. (2008) \\
\hline & 3 to 4 & - & Prince Edward Is. & Kaehler et al. (2000) \\
\hline \multirow[t]{2}{*}{ Euphausia superba } & $5.5 \pm 0.4^{\mathrm{a}}$ & - & Kerguelen & Cherel et al. (2008) \\
\hline & $4.3 \pm 1.0$ & $2.5 \pm 0.4$ & Scotia Sea & Stowasser et al. (2012) \\
\hline Thysanoessa spp. & $6.6 \pm 0.7$ & $3.1 \pm 0.2$ & Scotia Sea & Stowasser et al. (2012) \\
\hline Euphausia frigida & $5.7 \pm 0.9$ & $3.0 \pm 0.2$ & Scotia Sea & Stowasser et al. (2012) \\
\hline Euphausia triacantha & $7.2 \pm 0.9$ & $3.3 \pm 0.3$ & Scotia Sea & Stowasser et al. (2012) \\
\hline \multicolumn{5}{|l|}{ Fishes } \\
\hline Dissostichus eleginoides & $12.9 \pm 0.6$ & 5 & Kerguelen & Cherel et al. (2008) \\
\hline \multirow[t]{2}{*}{ Electrona antarctica } & $8.9 \pm 0.3$ & 3.8 & Kerguelen & Cherel et al. (2008) \\
\hline & $9.6 \pm 0.5$ & $4.0 \pm 0.1$ & Scotia sea & Stowasser et al. (2012) \\
\hline \multirow[t]{2}{*}{ Electrona carlsbergi } & $9.5 \pm 0.2$ & 3.9 & Kerguelen & Cherel et al. (2008) \\
\hline & $8.0 \pm 0.6$ & $3.7 \pm 0.2$ & Scotia sea & Stowasser et al. (2012) \\
\hline \multirow[t]{2}{*}{ Gymnoscopelus nicholsi } & $10.2 \pm 0.5$ & 4.2 & Kerguelen & Cherel et al. (2008) \\
\hline & $9.5 \pm 1.5$ & $4.2 \pm 0.3$ & Scotia Sea & Stowasser et al. (2012) \\
\hline \multirow[t]{2}{*}{ Krefftichtys anderssoni } & $7.6 \pm 0.2$ & 3.3 & Kerguelen & Cherel et al. (2008) \\
\hline & $8.4 \pm 0.5$ & $3.8 \pm 0.3$ & Scotia Sea & Stowasser et al. (2012) \\
\hline \multicolumn{5}{|l|}{ Cephalopods } \\
\hline \multirow[t]{2}{*}{ Architeuthis dux } & $11.6 \pm 1.3^{\mathrm{b}}$ & $4.6^{\mathrm{b}}$ & Kerguelen & Cherel et al. (2008) \\
\hline & $6.7 \pm 1.3^{\mathrm{c}}$ & - & Kerguelen & Cherel \& Hobson (2005) \\
\hline \multirow[t]{2}{*}{ Mesonichoteuthis hamiltoni } & $16.3 \pm 0.8^{\mathrm{b}}$ & $6.1^{\mathrm{b}}$ & Kerguelen & Cherel et al. (2008) \\
\hline & $11.4 \pm 0.8^{\mathrm{c}}$ & - & Kerguelen & Cherel \& Hobson (2005) \\
\hline \multirow[t]{2}{*}{ Martialia hyadesi } & $7.7 \pm 0.6^{\mathrm{b}}$ & $3.4^{\mathrm{b}}$ & Kerguelen & Cherel et al. (2008) \\
\hline & $2.8 \pm 0.6^{\mathrm{c}}$ & - & Kerguelen & Cherel \& Hobson (2005) \\
\hline \multirow{2}{*}{ Kondakovia longimana } & $9.2 \pm 1.1^{b}$ & $3.8^{\mathrm{b}}$ & Kerguelen & Cherel et al. (2008) \\
\hline & $4.3 \pm 1.1^{\mathrm{c}}$ & - & Kerguelen & Cherel \& Hobson (2005) \\
\hline \multirow[t]{2}{*}{ Gonatus antarcticus } & $13.3 \pm 0.5^{\mathrm{b}}$ & $5.2^{\mathrm{b}}$ & Kerguelen & Cherel et al. (2008) \\
\hline & $8.4 \pm 0.5^{c}$ & - & Kerguelen & Cherel \& Hobson (2005) \\
\hline \multirow[t]{2}{*}{ Mastigoteuthis psychrophila } & $12.8 \pm 0.6^{\mathrm{b}}$ & $5^{\mathrm{b}}$ & Kerguelen & Cherel et al. (2008) \\
\hline & $8.0 \pm 0.6^{\mathrm{c}}$ & - & Kerguelen & Cherel \& Hobson (2005) \\
\hline Galiteuthis glacialis & $8.7 \pm 0.1^{b}$ & $3.7 \pm 0.0^{\mathrm{b}}$ & Scotia Sea & Stowasser et al. (2012) \\
\hline Marine mammals & - & 3.2 to 4.6 & Global & Pauly et al. (1998) \\
\hline \multirow[t]{2}{*}{ Leptonychotes weddellii } & $13.3 \pm 0.1$ & - & McMurdo Sound & Burns et al. (1998) \\
\hline & $13.0 \pm 1.0$ & - & Ross Sea & Zhao et al. (2004) \\
\hline Hydrurga leptonyx & 7.7 to 14.3 & - & Prydz Bay & Hall-Aspland et al. (2005) \\
\hline Lobodon carcinophagus & $8.5 \pm 0.5$ & - & Ross Sea & Zhao et al. (2004) \\
\hline \multicolumn{5}{|l|}{ Seabirds } \\
\hline$\underline{\text { Procellariformes }}$ & & & & \\
\hline Procellaria aequinoctialis & 13 to 15.5 & - & South Georgia & Anderson et al. (2010) \\
\hline & $13.7 \pm 1.5$ & - & South Georgia & Stowasser et al. (2012) \\
\hline Diomedea exulans & 12.5 to 14.5 & - & South Georgia & Anderson et al. (2010) \\
\hline & $13.7 \pm 1.5$ & - & Crozet Is. & Jaeger et al. (2010) \\
\hline Thalassarche melanophrys & 9 to 13 & - & South Georgia & Anderson et al. (2010) \\
\hline & $15.9 \pm 0.8$ & - & South Georgia & Cherel et al. (2013) \\
\hline Pelecanoides urinatrix & 6.5 to 9 & & South Georgia & Anderson et al. (2010) \\
\hline Sphenisciformes & & & & \\
\hline Aptenodytes patagonicus & $10.1 \pm 0.2$ & - & Crozet Is. & Cherel et al. (2007) \\
\hline & $9.8 \pm 0.2$ & - & Kerguelen & Cherel et al. (2008) \\
\hline Eudyptes chrysolophus & $7.0 \pm 0.2$ & - & Crozet Is. & Cherel et al. (2007) \\
\hline & $9.8 \pm 0.2$ & - & South Georgia & Stowasser et al. (2012) \\
\hline
\end{tabular}


et al. 2000, Cherel et al. 2008, Stowasser et al. 2012). $M$. ingens (and M. knipovitchi) had a similar niche to $K$. longimana (Table 5), which was also within the expected range for a diet dominated by mesopelagic fish (myctophids and paralepids, Table 6) (Cherel \& Duhamel 2003).

The cephalopods which had the lowest $\delta^{15} \mathrm{~N}$ (apart from $M$. hyadesi and the onychoteuthids, Table 5) are likely to depend on zooplankton that feed in turn on sinking organic matter, since the measured $\delta^{15} \mathrm{~N}$ values were higher than expected from organisms that, in some cases, are characterized by gelatinous bodies and small size (except for Haliphron atlanticus, Fig. 7), e.g. cranchiids (Collins \& Rodhouse 2006). The sinking organic matter and detritus is generally enriched in ${ }^{15} \mathrm{~N}$ as a consequence of microbial decomposition during the transport to depth, which leads to an enrichment in the whole food web (including cephalopods) that is dependent on this resource (Michener \& Kaufman 2007).

G. antarcticus presented the highest $\delta^{15} \mathrm{~N}$ of all cephalopods in this study (apart from T. danae and the subtropical squids, Table 5). These high $\delta^{15} \mathrm{~N}$ values are just below those for the colossal squid Mesonychoteuthis hamiltoni (Cherel \& Hobson 2005, Cherel et al. 2008) (Table 6), which is considered a top invertebrate predator (Cherel \& Hobson 2005) that feeds on large fish and squid, and is found in the diet of sperm whales Physeter macrocephalus and sleeper sharks Somniosus cf. microcephalus (Clarke 1980, Cherel et al. 2004) (Table 6). This may probably be explained by a top predator position (by $G$. antarcticus) on a rather inefficient food web characterized by high ${ }^{15} \mathrm{~N}$ enrichment rates, dependent on heterotrophy of organic matter and detritus descending from epipelagic waters. As they are muscular squid with well-developed hooks, which is a sign of an active predator among squid, this species is a candidate for top predator within this environment (according to the isotope data), despite their small size relative to such megafauna as T. danae (Fig. 7) and $M$. hamiltoni.

T. danae is certainly one of the top predators amongst the squid inhabiting the deep ocean (Cherel et al. 2009b), as it shows a nitrogen isotope ratio at least as high as the giant squid Architeuthis dux, and within the range recorded in other studies (Cherel \& Hobson 2005, Cherel et al. 2009b) (Tables 5 \& 6). $T$. danae can also reach a considerable size (Fig. 7), with a maximum mantle length of $170 \mathrm{~cm}$ (Nesis 1987). The subtropical species Histioteuthis atlantica, C. akimushkini and Taonius sp. (Clarke) had the highest $\delta^{15} \mathrm{~N}$, probably due to the high baseline in subtropical waters (Altabet \& François 1994, Jaeger et al. 2010). C. akimushkini had the highest mean $\delta^{15} \mathrm{~N}$ value of all species, and there was a positive relationship between individual size and $\delta^{15} \mathrm{~N}$ in $H$. atlantica (Table 1, Fig. 7). This squid feeds higher in the food chain as it grows and is able to feed on progressively larger prey. Thus, ontogenetic variation has a potentially marked impact on $\delta^{15} \mathrm{~N}$ values in histioteuthids as it does in other species of ommastrephids and onychoteuthids (Cherel \& Hobson 2005, Cherel et al. 2009a, Lorrain et al. 2011).

Even though the various squid species in this study showed significant intra-specific differences in their niches across island groups, they generally remained in the same relative positions within the respective cephalopod communities. The exception was ?Mastigoteuthis sp. A (Clarke) which moved between the first group in Crozet to the second group in South Georgia (Figs. 2, 3, 4 \& 8).

Overall, the squid that live in Antarctic and subAntarctic waters were secondary to tertiary consumers, i.e. trophic level (TL) $>3$, which is near the average level for marine mammals $(\mathrm{TL}=\mathrm{ca} .4 .0$ [Pauly et al. 1998]), penguins ( $\mathrm{TL}=3.4-4.0$ [Stowasser et al. 2012]) other seabirds (TL $=3.7-5.2$ [Stowasser et al. 2012]), and sharks (TL > 4 [Cortés 1999]) (Table 6). Furthermore, the range of isotopic niches occupied by squid, and their wide horizontal and vertical distribution, shows parallels with the niches occupied by large pelagic fish (Rodhouse \& White 1995, Cortés 1999). Indeed, at depth, squid may be competing for prey with large, deep-diving mammals such as seals (Cherel et al. 2008). The most likely candidates for occupying the niche of large pelagic fish are the squids with the highest $\delta^{15} \mathrm{~N}$ that do not belong to the cranchiid or the mastigoteuthid/batoteuthid families, as the former are gelatinous and likely to be sluggish (Collins \& Rodhouse 2006) and the latter probably depend on the benthos (Roper \& Vecchione 1997); hence, the most active predators are presumably $G$. antarcticus, $T$. danae and $M$. knipovitchi (Figs. 2-5).

\section{CONCLUSIONS}

In conclusion, our study emphasizes that cephalopods have a wider and generally more complex (but well defined) pattern of distribution around the Southern Ocean than previously considered. Given the large range of $\delta^{13} \mathrm{C}$ and $\delta^{15} \mathrm{~N}$ values, cephalopods must occupy a diverse range of niches, from the middle of the food web (secondary consumers, $\mathrm{TL}=3$ ), to 
top predators (TL $>4$ ) in all the different water masses of the Southern Ocean. $\delta^{15} \mathrm{~N}$ in our samples corresponded broadly to those expected from previous conventional diet studies, or, with the exception of Martialia hyadesi, were somewhat higher, suggesting a greater representation of higher trophic prey. Although particular squid varied in their isotopic niche depending on the sampling site (island group), they did, however, occupy the same relative position within each community, apparently consisting of 3 main groups and one outlier (M. hyadesi). The most active, muscular and best-armed (hooked) cephalopod species with the highest $\delta^{15} \mathrm{~N}$ levels seem likely to occupy the niche of a top predator in pelagic ecosystems. Squid in general constitute a crucial and diverse component of Southern Ocean ecosystems, as not only are they widespread and abundant prey for marine top predators, but in addition, the mesoand bathypelagic species function as effective biological circulators by returning deep-sea carbon back to the surface, and vice-versa. Finally, our study demonstrates the value of new approaches for improving our understanding of the role of cephalopods in food webs, and in energy/carbon cycling in marine ecosystems.

Acknowledgements. The authors thank fieldworkers for collecting diet samples, Paul Rodhouse for numerous discussions on the paper and on cephalopods in general, Janet Silk for creating Fig. 1, and Alexandra Baeta for stable isotope analysis. The work at Crozet and Kerguelen was supported financially and logistically by the Institut Polaire Français Paul Emile Victor (Programme N¹09, H. Weimerskirch) and the Terres Australes et Antarctiques Françaises, and at South Georgia by the British Antarctic Survey. This work was also supported by the Fundação para a Ciência e Tecnologia (FCT), the British Antarctic Survey and within research projects CEPH, POLAR, PROPOLAR and international programs ICED and SCAR AnT-ERA. This study represents a contribution to the Ecosystems component of the British Antarctic Survey Polar Science for Planet Earth Programme, funded by the Natural Environment Research Council.

\section{LITERATURE CITED}

Altabet MA, François R (1994) Sedimentary nitrogen isotopic ratio as a recorder for surface ocean nitrate utilization. Global Biogeochem Cycles 8:103-116

> Anderson ORJ, Phillips RA, Shore RF, McGill RAR, McDonald RA, Bearhop S (2010) Element patterns in albatrosses and petrels: influence of trophic position, foraging range, and prey type. Environ Pollut 158:98-107

Burns JM, Trumble SJ, Castellini MA, Testa JW (1998) The diet of Weddell seals in McMurdo Sound, Antarctica as determined from scat collections and stable isotope analysis. Polar Biol 19:272-282
Cherel Y, Duhamel G (2003) Diet of the squid Moroteuthis ingens (Teuthoidea: Onychoteuthidae) in the upper slope waters of the Kerguelen Islands. Mar Ecol Prog Ser 250:197-203

Cherel Y, Hobson KA (2005) Stable isotopes, beaks and predators: a new tool to study the trophic ecology of cephalopods, including giant and colossal squids. Proc R Soc B 272:1601-1607

> Cherel Y, Hobson KA (2007) Geographical variation in carbon stable isotope signatures of marine predators: a tool to investigate their foraging areas in the Southern Ocean. Mar Ecol Prog Ser 329:281-287

Cherel Y, Klages N (1998) A review of the food of albatrosses. In: Robertson G, Gales R (eds) Albatross biology and conservation. Surrey Beatty and Sons, Chipping Norton, Australia, p 113-136

> Cherel Y, Weimerskirch H (1995) Seabirds as indicators of marine resources: black-browed albatrosses feeding on ommastrephid squids in Kerguelen waters. Mar Ecol Prog Ser 129:295-300

Cherel Y, Weimerskirch H (1999) Spawning cycle of onychoteuthid squids in the southern Indian Ocean: new information from seabird predators. Mar Ecol Prog Ser 188: 93-104

Cherel Y, Duhamel G, Gasco N (2004) Cephalopod fauna of subantarctic islands: new information from predators. Mar Ecol Prog Ser 266:143-156

> Cherel Y, Hobson KA, Guinet C, Vanpe C (2007) Stable isotopes document seasonal changes in trophic niches and winter foraging individual specialization in diving predators from the Southern Ocean. J Anim Ecol 76: 826-836

> Cherel Y, Ducatez S, Fontaine C, Richard P, Guinet C (2008) Stable isotopes reveal the trophic position and mesopelagic fish diet of female southern elephant seals breeding on the Kerguelen Islands. Mar Ecol Prog Ser 370: 239-247

> Cherel Y, Fontaine C, Jackson GD, Jackson CH, Richard P (2009a) Tissue, ontogenic and sex-related differences in $\delta^{13} \mathrm{C}$ and $\delta^{15} \mathrm{~N}$ values of the oceanic squid Todarodes filippovae (Cephalopoda: Ommastrephidae). Mar Biol 156: 699-708

- Cherel Y, Ridoux V, Spitz J, Richard P (2009b) Stable isotopes document the trophic structure of a deep-sea cephalopod assemblage including giant octopod and giant squid. Biol Lett 5:364-367

> Cherel Y, Jaeger A, Alderman R, Jaquemet S and others (2013) A comprehensive isotopic investigation of habitat preferences in nonbreeding albatrosses from the Southern Ocean. Ecography 36:277-286

Clarke MR (1977) Beaks, nets and numbers. Symp Zool Soc Lond 38:89-126

Clarke MR (1980) Cephalopoda in the diet of sperm whales of the Southern Hemisphere and their bearing on sperm whale biology. Discov Rep 37:1-324

Clarke MR (1983) Cephalopod biomass: estimation from predation. In: Stone DM (ed) Memoirs of the National Museum of Victoria, Vol 44. Museums Board of Victoria, Melbourne, p 95-107

> Collins MA, Rodhouse PGK (2006) Southern Ocean cephalopods. Adv Mar Biol 50:191-265

Cortés E (1999) Standardized diet compositions and trophic levels of sharks. ICES J Mar Sci 56:707-717

Croxall JP, Prince PA (1994) Dead or alive, night or day: how do albatrosses catch squid? Antarct Sci 6:155-162 
Deacon GER (1982) Physical and biological zonation in the Southern Ocean. Deep-Sea Res 29:1-15

- DeNiro MJ, Epstein S (1978) Influence of diet on the distribution of carbon isotopes in animals. Geochim Cosmochim Acta 42:495-506

DeNiro MJ, Epstein S (1981) Influence of diet on the distribution of nitrogen in animals. Geochim Cosmochim Acta 45:341-351

Fawcett SE, Lomas MW, Ward BB, Casey JR, Sigman DM (2011) Assimilation of upwelled nitrate by small eukaryotes in the Sargasso Sea. Nat Geosci 4:717-722

Hall-Aspland SA, Rogers TL, Canfield RB (2005) Stable carbon and nitrogen isotope analysis reveals seasonal variation in the diet of leopard seals. Mar Ecol Prog Ser 305: 249-259

> Hobson KA, Cherel Y (2006) Isotopic reconstruction of marine food webs using cephalopod beaks: new insight from captively raised Sepia officinalis. Can J Zool 84:766-770

Imber MJ (1992) Cephalopods eaten by wandering albatrosses (Diomedea exulans L.) breeding at six circumpolar localities. J R Soc N Z 22:243-263

> Jackson GD, Bustamante P, Cherel Y, Fulton A and others (2007) Applying new tools to cephalopod trophic dynamics and ecology: perspectives from the Southern Ocean Cephalopod Workshop, February 2-3, 2006. Rev Fish Biol Fish 17:79-99

> Jackson AL, Inger R, Parnell AC, Bearhop S (2011) Comparing isotopic niche widths among and within communities: SIBER - Stable Isotope Bayesian Ellipses in R. J Anim Ecol 80:595-602

> Jaeger A, Lecomte VJ, Weimerskirch H, Richard P, Cherel Y (2010) Seabird satellite tracking validates the use of latitudinal isoscapes to depict predators' foraging areas in the Southern Ocean. Rapid Commun Mass Spectrom 24: 3456-3460

Kaehler S, Pakhomov EA, Mcquaid CD (2000) Trophic structure of the marine food web at the Prince Edward Islands (Southern Ocean) determined by $\delta^{13} \mathrm{C}$ and $\delta^{15} \mathrm{~N}$ analysis. Mar Ecol Prog Ser 208:13-20

Kelly JF (2000) Stable isotopes of carbon and nitrogen in the study of avian and mammalian trophic ecology. Can J Zool 78:1-27

Lorrain A, Argüelles J, Alegre A, Bertrand A, Munaron JM, Richard P, Cherel Y (2011) Sequential isotopic signature along gladius highlights contrasted individual foraging strategies of jumbo squid (Dosidicus gigas). PLoS ONE 6: e22194

Michener RH Kaufman L (2007) Stable isotope ratios as tracers in marine food webs: an update. In: Michener RH, Lajtha K (eds) Stable isotopes in ecology and environmental science. Blackwell publishing, Oxford, p 248-252

Montoya JP (2007) Natural abundances of marine planktonic 15N. In: Michener RH, Lajtha K (eds) Stable isotopes in ecology and environmental science. Blackwell publishing, Oxford, UK, p 187-189

Nemoto T, Okiyama M, Takahashi M (1985) Aspects of the roles of squid in food chains of marine Antarctic ecosystems. In: Siegfried R, Condy PR, Laws RM (eds) Antarctic nutrient cycles and food webs. Springer-Verlag, Berlin, p 415-420

Nemoto T, Okiyama M, Iwasaki N, Kikuchi N (1988) Squid as predators of krill (Euphausia superba) and prey for sperm whales in the Southern Ocean. In: Sahrhage D (ed) Antarctic Ocean and resources variability. SpringerVerlag, Berlin, p 292-296
Nesis KN (1987) Cephalopods of the world (translated by B. S. Levitov and edited by L. A. Burgess). T. F. H. Publications, Neptune City, NJ

Park Y H, Gambéroni L, Charriaud E (1993) Frontal structure, water masses, and circulation in the Crozet Basin. J Geophys Res 98:12361-12385

Parnell AC, Inger R, Bearhop S, Jackson AL (2010) Source partitioning using stable isotopes: coping with too much variation. PLoS ONE 5:e9672

> Pauly D, Trites AW, Capuli E, Christensen V (1998) Diet composition and trophic levels of marine mammals. ICES J Mar Sci 55:467-481

Quillfeldt P, Masello JF, McGill RAR, Adams M, Furness RW (2010) Moving polewards in winter: a recent change in the migratory strategy of a pelagic seabird? Front Zool $7: 15$

Rodhouse PG (1990) Cephalopod fauna of the Scotia Sea at South Georgia: potential for commercial exploitation and possible consequences. In: Kerry KR, Hempel G (eds) Antarctic ecosystems: ecological change and conservation. Springer-Verlag, Berlin, p 289-298

Rodhouse PG, White MG (1995) Cephalopods occupy the ecological niche of epipelagic fish in the Antarctic Polar Frontal Zone. Biol Bull 189:77-80

Rodhouse PG, White M, Jones M (1992) Trophic relations of the cephalopod Martialia hyadesi (Teuthoidea: Ommastrephidae) at the Antarctic Polar Front, Scotia Sea. Mar Biol 114:415-421

Rodhouse PG, Prince PA, Trathan PN, Hatfield EMC and others (1996) Cephalopods and mesoscale oceanography at the Antarctic Polar Front: satellite tracked predators locate pelagic trophic interactions. Mar Ecol Prog Ser 136:37-50

Roper CFE, Vecchione M (1997) In situ observations test hypotheses of functional morphology in Mastigoteuthis (Cephalopoda, Oegopsida). Bull Mar Sci 71:893-901

Sackett WM, Eadie BJ, Exner ME (1974) Stable isotope composition of organic carbon in recent antarctic sediments. In: Tissot B, Bienner F (eds) Advances in organic chemistry 1973. Editions Technip, Paris, p 661-671

Stowasser G, Atkinson A, McGill RAR, Phillips RA, Collins MA, Pond DW (2012) Food web dynamics in the Scotia Sea in summer: A stable isotope study. Deep-Sea Res II 59-60:208-221

Trathan PN, Brandon MA, Murphy EJ (1997) Characterization of the Antarctic Polar Frontal Zone to the north of South Georgia in summer 1994. J Geophys Res 102: 10483-10497

Trull TW, Davies D, Casciotti K (2008) Insights into nutrient assimilation and export in naturally iron-fertilized waters of the Southern Ocean from nitrogen, carbon and oxygen isotopes. Deep-Sea Res II 55:820-840

Voss NA (1980) A generic revision of the Cranchiidae (Cephalopoda; Oegopsida). Bull Mar Sci 30:365-412

Voss NA, Nesis KN, Rodhouse PG (1998) The cephalopod Family Histioteuthidae (Oegopsida): systematics, biology, and biogeography. Smithson Contrib Zool 586:293-372

- Wada E, Terazaki M, Kabaya Y, Nemoto T (1987) ${ }^{15} \mathrm{~N}$ and ${ }^{13} \mathrm{C}$ abundances in the Antarctic Ocean with emphasis on the biogeochemical structure of the food web. Deep-Sea Res 34:829-841

Weimerskirch H, Salamolard M, Sarrazin F, Jouventin P (1993) Foraging strategy of wandering albatrosses through the breeding season: a study using satellite telemetry. Auk 110:325-342 
Xavier JC, Cherel Y (2009) Cephalopod beak guide for the Southern Ocean. British Antarctic Survey, Cambridge

Xavier JC, Croxall JP (2007) Predator-prey interactions: Why do larger albatrosses eat bigger squid? J Zool (Lond) 271: 408-417

Xavier JC, Rodhouse PG, Trathan PN, Wood AG (1999) A Geographical Information System (GIS) atlas of cephalopod distribution in the Southern Ocean. Antarct Sci 11: 61-62

Xavier JC, Croxall JP, Trathan PN, Wood AG (2003a) Feeding strategies and diets of breeding grey-headed and wandering albatrosses at South Georgia. Mar Biol 143: 221-232

Xavier JC, Croxall JP, Trathan PN (2003b) Inter-annual vari-

Editorial responsibility: Edward Durbin,

Narragansett, Rhode Island, USA ation in the cephalopod component of the diet of the wandering albatross, Diomedea exulans, breeding at Bird Island, South Georgia. Mar Biol 142:611-622

Xavier JC, Trathan PN, Croxall JP, Wood AG, Podestá G, Rodhouse PG (2004) Foraging ecology and interactions with fisheries of wandering albatrosses (Diomedea exulans) breeding at South Georgia. Fish Oceanogr 13: 324-344

> Xavier JC, Croxall JP, Cresswell KA (2005) Boluses: an effective method for assessing the proportions of cephalopods in the diet of albatrosses. Auk 122:1182-1190

Zhao L, Castellini MA, Mau TL, Trumble SJ (2004) Trophic interactions of Antarctic seals as determined by stable isotope signatures. Polar Biol 27:368-373

Submitted: January 10, 2014; Accepted: March 2, 2015

Proofs received from author(s): June 7, 2015 